\title{
石炭液化反応に拈けるガス/スラリー比 $(\mathrm{G} / \mathrm{L})$ の効果
}

（キーワード 石炭液化，気液平衡，ガス/スラリー比，ガスホールドアップ，蒸気圧）

\section{1. 緒言}

石炭液化に関する研究は従来より数多くなされてい るが，その多くはオートクレーブなどの回分式装置を 使用して行われてきた。しかし, 回分式装置ではガス 流通下で生起する気液平衡状態を考虑することは困難 である。すなわちガス流通下でスラリー中の溶剤の一 部が気相中に移行すると, 高温の反応器内では石炭あ るいは高沸点溶剤留分等の相対的に難蒸発成分の濃度 が上昇し，かつその滞留時間が延長される。したがっ て，スラリー中のこれらの成分に関してのみ選択的な 滞留時間の延長が起こり, その結果石炭の反応率が向 上する可能生が高いことが想定される。

そこでこの現象を把握するため, 石炭液化小型連続 装置を使用してガス/スラリ一供給量比 $(\mathrm{G} / \mathrm{L})$ あるい
は圧力の液収率に及ぼす影響に関して検討を実施した。 さらに, 液化反応塔内の気液平衡状態について子各種 の解析を試みた。

\section{2. 実 験}

\section{1 液化実験}

実験に使用したワンドアン炭, 太平洋炭およびイリ ノイNo.6 炭の性状分析值をTable 1 に示す。また触 媒, 溶剂および液化装置に関しては, 前報1) と同様の ものを用いた。さらに, 生成物の分析に関しても前 報1) と同様の操作を実施した。

\section{2 小型連続装置での気液平衡実験}

ガス/スラリー流量比 $(\mathrm{G} / \mathrm{L})$ を変化させた場合の連 続装置下での溶剤の気液平衡状態を把握するため, Fig. 1に示すよらに小型連続装置の第 2-反応器の液相

Table 1 Analyses of coals

\begin{tabular}{crcc}
\hline Coal & Wandoan & Taiheiyo & $\begin{array}{c}\text { Illinois No. } 6 \\
\text { Riverking }\end{array}$ \\
\hline $\begin{array}{c}\text { Proximate analysis } \\
\text { (wt\% as received) }\end{array}$ & & & \\
Moisture & 8.1 & 6.1 & 7.6 \\
Ash & 9.8 & 7.6 & 10.2 \\
VM & 44.6 & 48.4 & 40.4 \\
Ultimate analysis & & & \\
(wt\%, daf) & & & \\
C & 76.6 & 79.2 & 80.9 \\
H & 6.3 & 5.6 & 4.4 \\
N & 1.1 & 1.3 & 1.5 \\
S & 0.4 & 0.2 & 3.8 \\
Odiff. & 15.6 & 13.7 & 9.4 \\
\hline
\end{tabular}

石炭液化開発部 茨城県鹿島郡波崎町大字砂山 16 


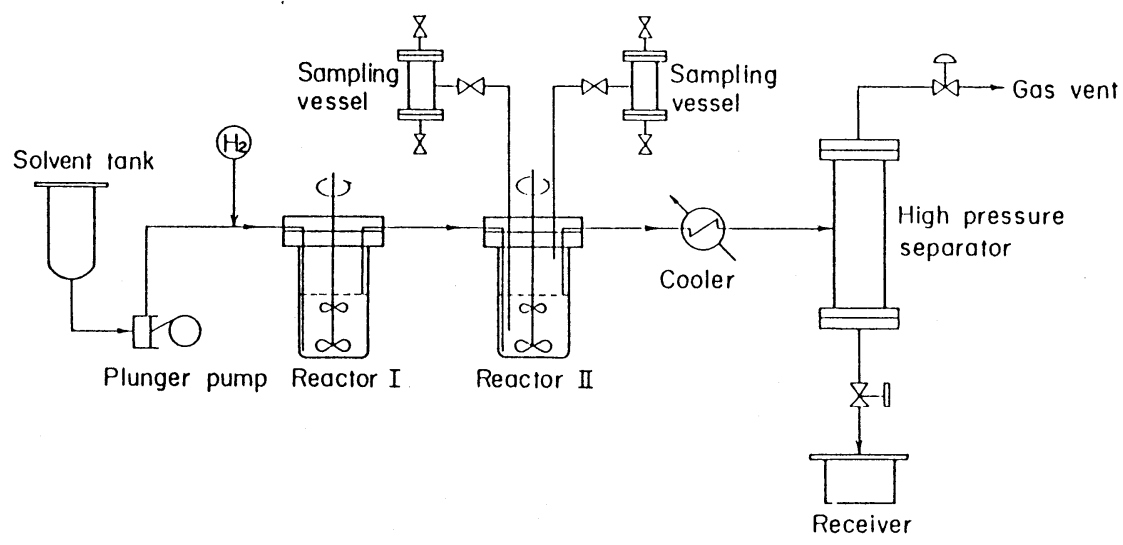

Fig. 1 Apparatus for the solvent vaporization

および気相部にサンプリング容器を設置した。温度 $450{ }^{\circ} \mathrm{C}$, 圧力 $150 \mathrm{~kg} / \mathrm{cm}^{2} \mathrm{G}$ の条件下で前報 ${ }^{1)}$ で用いた 吸収油とアントラセン油等量混合物の水素化処理油 （SS-1）を流通し，系内の気液平衡状態が達成された 時点で気相および液相部のサンプルを同時に採取した。 採取したサンプルは蒸留 GCで成分分析を実施した。

\section{3 溶剂留分の精密蒸留と物性測定}

反応器内気液平衡状態の解析の一環として, 予め試 料を細分別した後各フラクションの物性を測定した。

2.3 .1 精密蒸留 柴田科学製理論段数60段の充 填式精密蒸留塔を使用し，SS-1および $1 \mathrm{t} / \mathrm{d}$ PDU装 置 ${ }^{2)}$ で製造したイリノイNo.6炭の平衡溶剤を10フラ クションに細分別した。分別後のフラクションは蒸留 $\mathrm{GC}$ で分析し，その50\%留出温度を各フラクションの 平均沸点とした。

\section{3 .2 蒸気圧測定 Fig. 2 に示す示差圧測定装} 置を用いて溶剤留分の蒸気圧を測定した。先ず同一の 内容積 $(100 \mathrm{cc})$ を有した 2 本の反応器のらちの反応室 (S) 側に試料約 $20 \mathrm{~g}$ を充填し，次に系内を窒素置換 した後毎分 $5{ }^{\circ} \mathrm{C}$ 昇温速度で所定温度まで昇温した。 なお昇温中予め設定された数点の任意の温度で30分間 ホールドし，各温度における蒸気圧を測定した。

2.3 .3 分子量測定 KNAUER 製1100型蒸気圧 浸透式分子量測定装置を使用し，クロロホルムを溶媒 としてSS-1溶剤の平均分子量を測定した。

\section{3. 結果および考察}

\section{$3.1 \mathrm{G} / \mathrm{L}$ と液收率との関係}

反応温度 $450^{\circ} \mathrm{C}$, 空塔基準のみかけの滞留時間 60 分 および圧力 $150 \mathrm{~kg} / \mathrm{cm}^{2} \mathrm{G}$ の条件下で，スラリ一流量 $(\mathrm{L})$ は 5 l / h で一定とし， $\mathrm{H}_{2}$ ガス流量 $(\mathrm{G})$ を変化させること によって G/Lを種々変化させた場合の生成物収率を

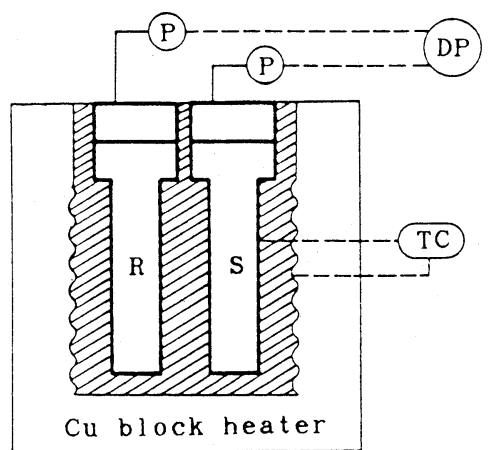

Fig. 2 Schematic diagram of high pressure DPA

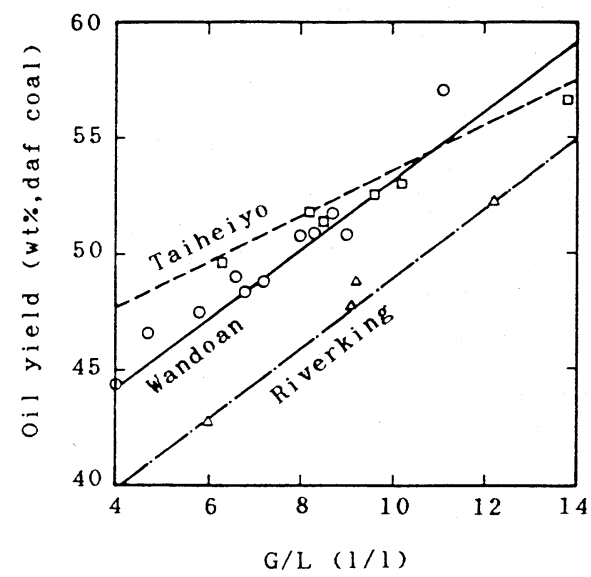

Fig. 3 Effect of gas-slurry ratio on oil yield at $150 \mathrm{~kg} / \mathrm{cm}^{2} \mathrm{G}$

Table 2に示す。また, Fig. 3 および 4 にはTable 2 の 液収率あるいは残渣収率と $\mathrm{G} / \mathrm{L}$ との関係をプロット した。 
Table 2 Effect of $\mathrm{G} / \mathrm{L}$ on products yield at $450^{\circ} \mathrm{C}, 60 \mathrm{~min}, 150 \mathrm{~kg} / \mathrm{cm}^{2} \mathrm{G}$

\begin{tabular}{|c|c|c|c|c|c|c|c|}
\hline \multirow{3}{*}{\multicolumn{2}{|c|}{$\begin{array}{r}\text { Coal G/L } \\
(\ell / \ell)\end{array}$}} & \multicolumn{6}{|c|}{ Yield (wt $\%$, daf coal) } \\
\hline & & \multirow[t]{2}{*}{ Gas } & \multirow[t]{2}{*}{ Water } & \multicolumn{3}{|c|}{- Oil $\longrightarrow$} & \multirow[t]{2}{*}{ Residue } \\
\hline & & & & $\mathrm{L}-\mathrm{O}$ & $\mathrm{H}-\mathrm{O}$ & Total & \\
\hline W & 4. 1 & 15.0 & 6.2 & 19. 0 & 25.4 & 44.4 & 36.6 \\
\hline W & 4. 7 & 13.8 & 6.0 & 20.4 & 26.2 & 46.6 & 36.3 \\
\hline W & 5.8 & 13.5 & 4. 6 & 20.1 & 27.4 & 47.5 & 37.1 \\
\hline W & 6.6 & 13. 0 & 7. 7 & 19.8 & 29.2 & 49.0 & 32.6 \\
\hline W & 6.8 & 15.7 & 7.1 & 20.9 & 27.5 & 48. 4 & 32.1 \\
\hline W & 7. 2 & 14. 3 & 6.9 & 20.4 & 28.4 & 48. 8 & 32.9 \\
\hline W & 8.0 & 13.8 & 5.3 & 18. 1 & 32.7 & 50.8 & 32.6 \\
\hline W & 8.3 & 13.5 & 6.4 & 20.5 & 30.4 & 50.9 & 31.9 \\
\hline W & 8.7 & 14.5 & 6. 9 & 19.8 & 32.0 & 51.8 & 29.9 \\
\hline W & 9.0 & 14.6 & 7. 3 & 21.0 & 29.8 & 50.8 & 30.5 \\
\hline W & 11.1 & 13.5 & 5.8 & 20.8 & 36.2 & 57.0 & 27.0 \\
\hline $\mathrm{T}$ & 6.3 & 14. 0 & 7.3 & 13.1 & 36.5 & 49.6 & 32.4 \\
\hline $\mathrm{T}$ & 8. 2 & 13.8 & 7. 0 & 10.7 & 41.1 & 51.8 & 31.0 \\
\hline $\mathrm{T}$ & 8.5 & 12.6 & 6.9 & 12.7 & 38.7 & 51.4 & 32.4 \\
\hline $\mathrm{T}$ & 9.6 & 13.0 & 7. 1 & 12. 2 & 40.3 & 52.5 & 31.0 \\
\hline $\mathrm{T}$ & 10. 2 & 13.4 & 6.4 & 13.0 & 40.0 & 53. 0 & 30.7 \\
\hline $\mathrm{T}$ & 13.8 & 13.4 & 7.3 & 15.4 & 41.2 & 56.6 & 27.2 \\
\hline $\mathrm{R}$ & 6.0 & 10.8 & 5.0 & 14.6 & 28.1 & 42.7 & 45.0 \\
\hline $\mathrm{R}$ & 9.1 & 10.9 & 6.8 & 15.8 & 32.0 & 47.8 & 38.8 \\
\hline $\mathrm{R}$ & 9.2 & 11.6 & 6.2 & 16.0 & 32.8 & 48.8 & 37.2 \\
\hline $\mathrm{R}$ & 12.2 & 11.1 & 7.0 & 16.5 & 35.7 & 52.2 & 34.2 \\
\hline
\end{tabular}

W: Wandoan $\mathrm{T}$ : Taiheiyo $\mathrm{R}$ : Riverking $\mathrm{L}-\mathrm{O}: \mathrm{IBP}-220^{\circ} \mathrm{C} \quad \mathrm{H}-\mathrm{O}: 220-538^{\circ} \mathrm{C}$

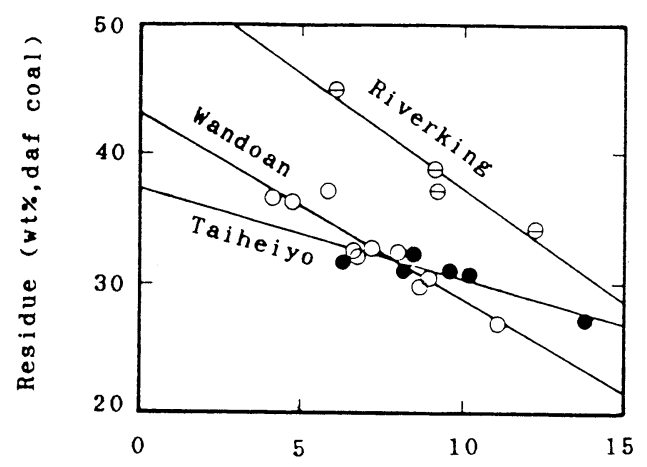

$\mathrm{G} / \mathrm{L}(1 / 1)$

Fig. 4 Relation between residue yield and $\mathrm{G} / \mathrm{L}$ at $150 \mathrm{~kg} / \mathrm{cm}^{2} \mathrm{G}$

Fig. 3 より炭種に依らず $\mathrm{G} / \mathrm{L}$ の増大と共に液収率が 向上寸ることがわかる。さらにFig. 4 からは，G/Lの 増大で残椬収率が減少することがわかる。したがって G/L の増大は, 未反応炭等の重質成分の分解を助長 し，その結果として液収率を向上させる効果を有して
いると考えられる。一方, Table 2 でG/L と他の生成 物収率との関係についてみると，ガスおよび水収率共 に G/Lを増大させてもほとんど変化しない。さらに 液化油の中の沸点 $220^{\circ} \mathrm{C}$ 以下の軽質油の生成量も同様 に G/Lを増大させても変化しない。したがって, こ れらの結果から見ると, $\mathrm{G} / \mathrm{L}$ の増大効果は未反応炭 もしくは沸点 $538^{\circ} \mathrm{C}$ 以上の重質油の $\mathrm{H}-\mathrm{O}(\mathrm{bp} 220$ $\left.538^{\circ} \mathrm{C}\right)$ への転化反応を促進する点にあると考えられ る。

$\mathrm{G} / \mathrm{L}$ の効果をさらに検討するため圧力を $190 \mathrm{~kg} /$ $\mathrm{cm}^{2} \mathrm{G}$ に増大させて液化実験を実施したが，その結果 をFig. 5 に示す。圧力 $150 \mathrm{~kg} / \mathrm{cm}^{2} \mathrm{G}$ の場合と同様, 液 収率はここでも $\mathrm{G} / \mathrm{L}$ と良好な相関を有していること がわかる。そこで, Fig. 3 执よびFig. 5 の結果をもと に各炭種について $\mathrm{G} / \mathrm{L}, \mathrm{H}_{2}$ 分圧と液収率との関係式 の導出を試みたところ，(1)式に示す一般式で整理でき ることが判明した。

$$
\mathrm{Y}_{0}=\left(\mathrm{A}_{1} \sqrt{\mathrm{P}_{\mathrm{H}_{2}}}-\mathrm{B}_{1}\right)(\mathrm{G} / \mathrm{L})+\mathrm{C}_{1}
$$






Fig. 5 Effect of gas-slurry ratio on oil yield at $190 \mathrm{~kg} / \mathrm{cm}^{2} \mathrm{G}$

Table 3 Estimated constants of equation (1)

\begin{tabular}{cccc}
\hline Coal & $\mathrm{A}_{1}$ & $\mathrm{~B}_{1}$ & $\mathrm{C}_{1}$ \\
\hline Wandoan & 0.38 & 3.16 & 38.2 \\
Taiheiyo & 0.17 & 1.09 & 43.8 \\
Riverking & 0.23 & 1.29 & 33.9 \\
\hline
\end{tabular}

$\mathrm{Y}_{0}:$ 液 $\left(\mathrm{IBP}-538^{\circ} \mathrm{C}\right)$ 収率 $[\mathrm{wt} \%, \mathrm{daf}$ coal]

$\mathrm{P}_{\mathrm{H}_{2}}:$ 水素分圧 $\left[\mathrm{kg} / \mathrm{cm}^{2} \mathrm{G}\right]$

$\mathrm{G} / \mathrm{L}$ : 反応温度, 圧力下のガス/スラリー 比 $[\ell / \ell]$

$\mathrm{A}_{1}, \mathrm{~B}_{1}, \mathrm{C}_{1}$ : 定数

また(1)式の石炭種毎の各定数は, Table 3 に示す値 となる。このようにして求めた石炭種毎の相関式を

Fig. 3 および 5 の各直線で示すが，実験データをほぼ 精度よく反映していることがわかる。

一方，残渣収率 $\left(\mathrm{Y}_{\mathrm{s}}\right)$ に関しても同様に回帰式を求 めれば(2)式が得られ，また各定数はTable 4 に示す值 となる。

$$
\mathrm{Y}_{\mathrm{s}}=-\left(\mathrm{A}_{2} \sqrt{\mathrm{P}_{\mathrm{H}_{2}}}-\mathrm{B}_{2}\right)(\mathrm{G} / \mathrm{L})+\mathrm{C}_{2}
$$

\section{2 溶剂蒸発量の実測}

G/L と共に液収率が向上する原因を把握するため, Fig. 1 の装置を使用して溶剂の気液平衡実験を実施し た。取得したサンプルの蒸留 GC 分析結果の一例を Fig. 6に示す。図より, 高温高圧の反応器内ではおも に溶剂中の比較的軽質成分が気相側に移行しているこ とがわかる。

ここで, 溶剤全体の液相および気相への重量分配比
Table 4 Estimated constants of equation (2)

\begin{tabular}{lcrc}
\hline \multicolumn{1}{c}{ Coal } & $\mathrm{A}_{2}$ & \multicolumn{1}{c}{$\mathrm{B}_{2}$} & \multicolumn{1}{c}{$\mathrm{C}_{2}$} \\
\hline Wandoan & 0.105 & -0.15 & 43.1 \\
Taiheiyo & 0.098 & 0.38 & 38.5 \\
Riverking & 0.235 & 1.13 & 37.3 \\
\hline
\end{tabular}

Table 5 Liquid and vapor phase distribution ratio

\begin{tabular}{ccc}
\hline $\mathrm{G} / \mathrm{L}(\ell / \ell)$ & $\mathrm{X}_{\mathrm{L}}(-)$ & $\mathrm{X}_{\mathrm{V}}(-)$ \\
\hline 4.9 & 0.78 & 0.22 \\
7.4 & 0.70 & 0.30 \\
13.2 & 0.48 & 0.52 \\
\hline
\end{tabular}



Fig. 6 Distillation curves of samples at $\mathrm{G} / \mathrm{L}=7.4 \ell / \ell$

を $\mathrm{X}_{\mathrm{L}}, \mathrm{X}_{\mathrm{V}}$ とすれば，(3)式が成立する。

$\mathrm{X}_{\mathrm{L}}+\mathrm{X}_{\mathrm{V}}=1$

今回の実験手法では気相, 液相の全重量を測定する ことができず， $\mathrm{X}_{\mathrm{L}}$ もしくは $\mathrm{X}_{\mathrm{V}}$ を直接知ることができ ないため, 両分配比は以下の方法によって算出した。 すなわち今，溶剤中のi成分(フラクション)に関して は(4)式が成立する。

$$
\mathrm{ws}_{\mathrm{i}}=\mathrm{X}_{\mathrm{L}} \cdot \mathrm{w}_{\mathrm{i}}+\mathrm{X}_{\mathrm{V}} \cdot \mathrm{wv}_{\mathrm{i}}
$$

ここで $\mathrm{ws}_{\mathrm{i}}, \mathrm{w} \ell_{\mathrm{i}} お$ よび $\mathrm{wv}_{\mathrm{i}}$ はおのおの溶剂，液相 および気相中の $\mathrm{i}$ 成分の重量分率を示し, $\mathrm{w}_{\mathrm{i}}, \mathrm{wv}_{\mathrm{i}}$ はそれぞれ気相および液相から取得したサンプルの蒸 留曲線より得ることができる。そこで各蒸留曲線を $0 \sim 550^{\circ} \mathrm{C}$ の範囲で550 分割し，おのおのの分割成分 $\mathrm{i}$ に対し $\mathrm{w} \ell_{\mathrm{i}}, \mathrm{wv}_{\mathrm{i}}$ を求め, (4)式で得た $\mathrm{ws}_{\mathrm{i}}$ が元の溶剂 蒸留曲線から得た $\mathrm{i}$ 成分の全体に対する割合と最も良 くフィットする $\mathrm{X}_{\mathrm{L}}$ および $\mathrm{X}_{\mathrm{V}}$ を試行錯誤法で探索した。 その結果をTable 5 に示す。これより $\mathrm{G} / \mathrm{L}$ の増大と共 
に溶剤の気相への移行量すなわち蒸発量が増大し

ていることがわかる。

\section{3 溶剂蒸発量の推算}

G/Lの増大によって溶剤の蒸発量が増大する ことが明かとなったが, 以下ではこの溶剤蒸発量 を推算する手法について検討を試みた。

3.3 .1 液相分配比 $\left(\mathrm{X}_{\mathrm{R}}\right) \quad$ 今, 温度 $\mathrm{t}$, 全圧 $\mathrm{P}_{\mathrm{T}}$ の反応器内気相に水素ガスと溶剂蒸気が存在 し, これらが理想気体の挙動を示すものとすれば, (5)，(6)式が成立する。

$\mathrm{P}_{\mathrm{T}}=\mathrm{P}_{\mathrm{H}}+\mathrm{P}_{\mathrm{V}}$

$$
\frac{\mathrm{P}_{\mathrm{V}}}{\mathrm{P}_{\mathrm{H}}}=\frac{\mathrm{V}_{\mathrm{V}}}{\mathrm{V}_{\mathrm{H}}}
$$

ここで $\quad \mathrm{P}_{\mathrm{T}}:$ 全圧 $[\mathrm{atm}]$

$\mathrm{P}_{\mathrm{V}}:$ 溶剂蒸気圧 $[\mathrm{atm}]$

$\mathrm{P}_{\mathrm{H}}:$ 水素ガス分圧 $[\mathrm{atm}]$

$\mathrm{V}_{\mathrm{V}}$ : 温度 $\mathrm{t}$, 圧力 $\mathrm{P}_{\mathrm{T}}$ での溶剤蒸気量 $[\mathrm{l}]$

$\mathrm{V}_{\mathrm{H}}$ : 温度 $\mathrm{t}$ ，圧力 $\mathrm{P}_{\mathrm{T}}$ での水素ガス量 $[\mathrm{l}]$

また， $\mathrm{V}_{\mathrm{M}}$ を反応器への流入溶剂が全量蒸気になっ たときの量とすれば，溶剤の液相分配比 $\left(\mathrm{X}_{\mathrm{R}}\right)$ は(7)式 で示される。

$$
\mathrm{X}_{\mathrm{R}}=1-\frac{\mathrm{V}_{\mathrm{V}}}{\mathrm{V}_{\mathrm{M}}}
$$

ここで, 溶剤の比重を 1 とすると, $\mathrm{V}_{\mathrm{M}}$ は(8)式で示 されまた $\mathrm{V}_{\mathrm{H}}$ はと等しい。

$$
\mathrm{V}_{\mathrm{M}}=\frac{22400}{\mathrm{M}_{\mathrm{w}}} \cdot \frac{273+\mathrm{t}}{273} \cdot \frac{\mathrm{L}}{\mathrm{P}_{\mathrm{T}}}
$$

$\mathrm{V}_{\mathrm{H}}=\mathrm{G}$

ここで $\mathrm{M}_{\mathrm{w}}$ : 溶剤の平均分子量 $[\mathrm{g} / \mathrm{mol}]$

$$
\begin{aligned}
& \mathrm{t}: \text { 温度 }\left[{ }^{\circ} \mathrm{C}\right] \\
& \mathrm{L}: \text { 液 }(\text { 溶剤) 流量 }[\ell / \mathrm{h}] \\
& \mathrm{G}: \mathrm{t}{ }^{\circ} \mathrm{C}, \mathrm{P}_{\mathrm{T}} \text { atm でのガス流量 }[\mathrm{l} / \mathrm{h}]
\end{aligned}
$$

(5)〜(9)式を整理すると， $\mathrm{X}_{\mathrm{R}}$ は(10)式で示される。

$$
\mathrm{X}_{\mathrm{R}}=1-\frac{\mathrm{M}_{\mathrm{w}}}{22400} \cdot \frac{273}{273+\mathrm{t}} \cdot \frac{\mathrm{P}_{\mathrm{V}}}{\mathrm{P}_{\mathrm{T}}-\mathrm{P}_{\mathrm{V}}} \cdot \mathrm{P}_{\mathrm{T}}(\mathrm{G} / \mathrm{L})
$$

したがって, 溶剤の平均分子量 $\left(\mathrm{M}_{\mathrm{w}}\right)$ と蒸気圧 $\left(\mathrm{P}_{\mathrm{V}}\right)$ が知れれば, 任意の温度, 圧力での液相分配比と $\mathrm{G} / \mathrm{L}$ との関係が求まることになる。

3.3 .2 溶剂の平均分子量 $\left(\mathrm{M}_{\mathrm{w}}\right)$ 溶剤の平均分子 量の推算式を導出するために, SS-1 溶剤を精密蒸留 によって細分別したフラクションの平均分子量を実測 したが，その結果をFig. 7亿示す。図より分子量と沸

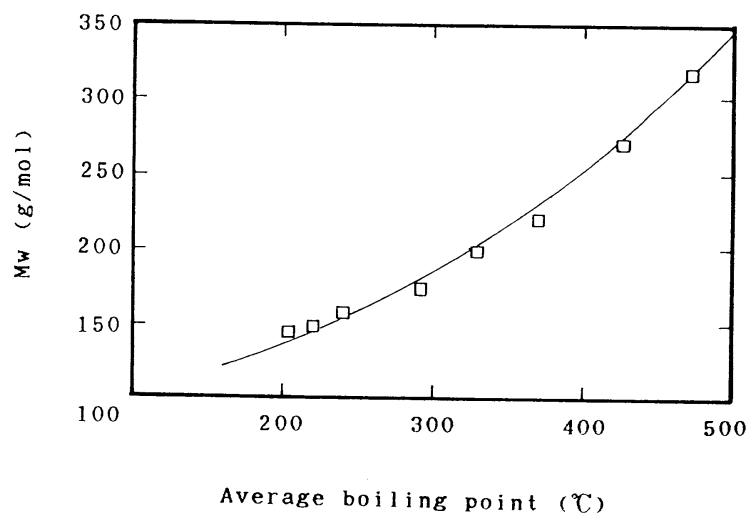

Fig. 7 Relation between molecular weight and average boiling point

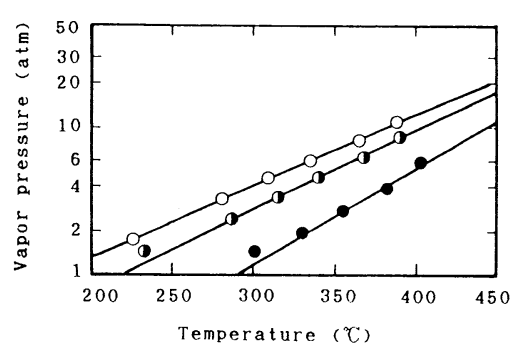

O: bp $220-240^{\circ} \mathrm{C}\left(\overline{\mathrm{BP}}=224^{\circ} \mathrm{C}\right) \mathrm{fract}$ i on : bp $240-260^{\circ} \mathrm{C}\left(\mathrm{BP}=243^{\circ} \mathrm{C}\right)$
: bp2 $80-300^{\circ} \mathrm{C}\left(\mathrm{BP}=282^{\circ} \mathrm{C}\right)$

Fig. 8 Relation between vapor pressure and temperature

点とが一定の相関を有していることがわかるが，この 関係は(11)式の形で整理できた。さらに，(11)式を図示す ればFig. 7 の実線となる。

$$
\mathrm{M}_{\mathrm{w}}=\exp \left[3.118 \times 10^{-3} \mathrm{BP}+4.291\right]
$$

$\mathrm{BP}$ : 溶剤平均沸点 $\left[{ }^{\circ} \mathrm{C}\right]$

3.3 .3 溶剤の蒸気圧 $\left(\mathrm{P}_{\mathrm{V}}\right)$ 溶剤の蒸気圧の推算 式を導出するためにイリノイNo.6リバーキング炭平 衡溶剂細分別フラクションの蒸気圧を測定したが，そ の結果をFig. 8亿示す。この関係を整理するために, 先ず各フラクションの温度と蒸気圧との関係に対して Antoine式3)の適用を試みた。

$\log P_{V}=A-\frac{B}{C+t}$ Antoine's eq.

ここで A, B, C : Antoine定数

その結果, 各フラクションの蒸気圧はFig. 8 の実線 で示す様にAntoine式でほほ濪度良く整理できた。な お，このときのAntoine 定数はTable 6 亿示すような 値となった。

しかしこのままでは各フラクションの平均沸点と蒸 
Table 6 Constants of Antoine's equation

\begin{tabular}{cccc}
\hline \multirow{2}{*}{$\begin{array}{c}\text { Solvent BP } \\
\left({ }^{\circ} \mathrm{C}\right)\end{array}$} & $\mathrm{A}$ & $\mathrm{B}$ & $\mathrm{C}$ \\
\cline { 2 - 4 } & 30.7871 & 190671 & 6063.16 \\
205 & 31.3996 & 195123 & 6037.80 \\
224 & 34.3807 & 212311 & 5958.19 \\
243 & 37.7453 & 213173 & 5359.26 \\
282 & 38.2971 & 210937 & 5196.00 \\
\hline 329 & & & \\
\hline
\end{tabular}

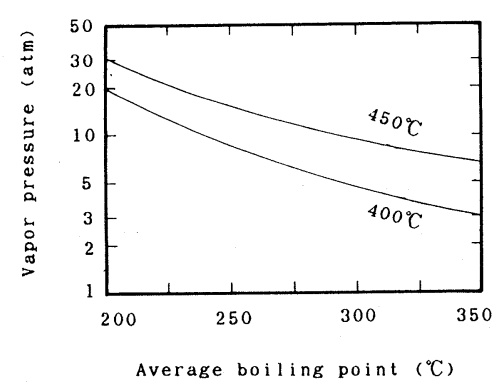

Fig. 9 Dependence of vapor pressure upon average boiling point

気圧との関係が不明確であるため，Table 6 の值を使 用して溶剂の平均沸点と蒸気圧, 温度との関係につい て検討を行ってみたところ，次式が得られた。(12)式の 関係の一例をFig. 9に図示した。

$$
\begin{aligned}
& \log P_{V}=X_{1}+\frac{X_{2}}{X_{3}} \ldots \ldots \ldots \ldots \ldots \\
& X_{1}=0.0132 t-6.11 \ldots \ldots \ldots \ldots \\
& X_{2}=-2.8 t+1629 \ldots \ldots \ldots \ldots \ldots \\
& X_{3}=-0.349 t+177.8+B P
\end{aligned}
$$

以上より, 溶剤の平均沸点が知れていれば(11)式よ り $\mathrm{M}_{\mathrm{w}}$ が，また(12)式より $\mathrm{P}_{\mathrm{V}}$ が算出でき，その結果(10) 式から任意の温度, 圧力における液相分配比 $\left(\mathrm{X}_{\mathrm{R}}\right)$ と G/L との関係を求めることが可能である。そこで, 先に3.2で実測した溶剤蒸発量と(10)式による推算値と の比較を行ってみたが，その結果をFig. 10 に示す。 図中の実線は(10)式で求めた推算值であるが, 各 $\mathrm{G} / \mathrm{L}$ の場合について概ね実験データと良く一致することが 認められた。したがって, 反応器内での溶剤の蒸発状 況は，(10)式によって推算可能であると考えられる。

\section{$3.4 \mathrm{G} / \mathrm{L}$ の反応器内滞留時間としての評価}

G/Lの増大と共に液収率が向上する現象は, 溶剤 留分の蒸発量の増加に起因していると考えられる。す なわち, 溶剤留分の蒸発によって固体石炭あるいは重 質留分等の難蒸発成分の反応器内滞留時間が延長され

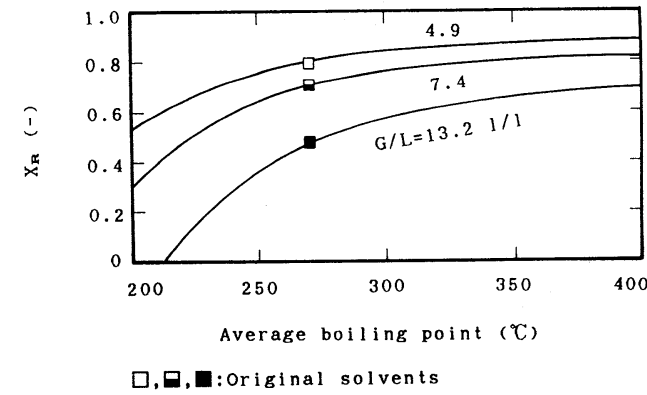

Fig. 10 Dependence of liquid phase weight fraction upon average boiling point at several gas-solvent ratio

るため，これらの成分の液化反応が促進されて液収率 が向上すると考えられる。したがって，G/Lの効果 を定量的に評価するためには，G/L と共に反応時間 がどの程度延長されているかを把握する必要がある。 そこで，以下ではこの反応時間に関して検討を試みた。

3.4 .1 スラリーの反応器内滞留時間連続装置 での反応時間(平均滞留時間)は, 一般的には空塔基準 に基づく(16)式の形で示される。

$$
\mathrm{t}_{\mathrm{N}}=\frac{\mathrm{V}}{\mathrm{F}_{\mathrm{L}}}
$$

$\mathrm{t}_{\mathrm{N}}:$ 空塔基準平均滞留時間 $[\mathrm{hr}]$

$\mathrm{V}$ : 反応器容積 $[\ell]$

$\mathrm{F}_{\mathrm{L}}$ : スラリー流量 $[\mathrm{l} / \mathrm{hr}]$

一方, 液化反応器内ではスラリー中の一部の成分 が蒸発するため, 実際のスラリ一相流量は(16)式の值よ りも低下する。そこで今スラリ一相残存率を $\mathrm{Y}_{\mathrm{R}}$ とす れば，真のスラリー流量は $F_{L} \cdot Y_{R}$ で示される。さら に, 一般的な気泡塔型反応塔では反応器容積の一定割 合をガスが占有するため, ガスホールドアップ量を $\varepsilon_{\mathrm{g}}$ とすると，スラリーに対する有効容積は $\left(1-\varepsilon_{\mathrm{g}}\right) \cdot \mathrm{V}$ と なる。故に, この両者を考慮したスラリーの真の滞留 時間は次式で示される。

$$
t_{R}=\frac{\left(1-\varepsilon_{g}\right) \cdot V}{F_{L} \cdot Y_{R}}
$$

$\mathrm{t}_{\mathrm{R}}:$ 真の滞留時間 $[\mathrm{hr}]$

$\varepsilon_{\mathrm{g}}:$ ガスホールドアップ[一]

$\mathrm{Y}_{\mathrm{R}}$ : スラリー相残存率 $[$ - $]$

今，滞留時間がぞの程度延長されているかを示す指 数 $(\theta)$ を次式で定義する。

$$
\theta=\frac{t_{R}}{t_{N}}
$$

したがって(16)，(17)式より 
$\theta=\frac{\left(1-\varepsilon_{g}\right)}{\mathrm{Y}_{\mathrm{R}}}$

故に $\theta$ を求めるためには $\varepsilon_{\mathrm{g}}$ と $\mathrm{Y}_{\mathrm{R}}$ の值を知る必要があ る。

3.4 .2 反応器形状と $\varepsilon_{\mathrm{g}}$ 液化反応塔内のガス ホールドアップに関しては, Tarmy ら)あるいは石橋 ら5)によって測定されているが，ここでは石橋らの導 出した(20)式を用いて $\varepsilon_{g}$ の検討を試みた。

$$
\frac{\varepsilon_{\mathrm{g}}}{1-\varepsilon_{\mathrm{g}}}=0.113 \mathrm{U}_{\mathrm{go}}{ }^{1.2}
$$

ここで $\mathrm{U}_{\mathrm{go}}$ ：ガス空塔速度 $[\mathrm{cm} / \mathrm{s}]$

この(20)式を使用して各 $\mathrm{G} / \mathrm{L}$ における $\varepsilon_{\mathrm{g}}$ を圧力 $170 \mathrm{~kg} / \mathrm{cm}^{2}$ の場合について計算すると, 塔高/塔径比 $(\mathrm{L} / \mathrm{D})$ が 4 以下の小型連続装置反応器では, G/L が $200 \sim 1000 \mathrm{~N} \ell / \ell$ のきの $\mathrm{U}_{\mathrm{g} 0}$ は0. 03〜0.14であり, このときの $\varepsilon_{\mathrm{g}}$ は 0.01 以下となるために零と見なして も差し支えないと考光られる。一方 L/D が 36 の $1 \mathrm{t} / \mathrm{dPDU}$ 装置では, 同様の $\mathrm{G} / \mathrm{L}$ のきの $\mathrm{U}_{\mathrm{go}}$ は 0.7 3.7 であり，(20)式によれば $\varepsilon_{g} は 0.07 〜 0.35$ となる。

3.4 .3 スラリ一相残存率 液相が溶剂留分のみ の系での反応器内の夜相残存率は(10)式で容易に推算で きるが，液相が反応を伴ら石炭スラリ一系の場合には その推算は複雑となる。そこで, ここでは系を単純化 しながら，スラリー相残存率を推算した。

先ずスラリー中の石炭分率を $\mathrm{W}_{\mathrm{c}}$, 溶剤分率を $\mathrm{W}_{\mathrm{L}}$ とした場合(21)式が成立するものとする。

$$
\mathrm{W}_{\mathrm{c}}+\mathrm{W}_{\mathrm{L}}=1
$$

次に, 液化反応時の液収率を $\mathrm{Y}_{\mathrm{o}}$, 残渣収率を $\mathrm{Y}_{\mathrm{s}}$ と し，また生成した液が溶剂と同等の取扱が可能である とすれば，ある $\mathrm{G} / \mathrm{L} の$ 条件下でのスラリー相残存率( $\mathrm{Y}_{\mathrm{R}}$ )は(22)式で示される。

$$
\begin{aligned}
& \mathrm{Y}_{\mathrm{R}}=\mathrm{X}_{\mathrm{R}}\left(\mathrm{Y}_{\mathrm{o}} \cdot \mathrm{W}_{\mathrm{c}}+\mathrm{W}_{\mathrm{L}}\right)+\mathrm{Y}_{\mathrm{s}} \cdot \mathrm{W}_{\mathrm{c}} \cdots \cdots \ldots \ldots \ldots \ldots \ldots \ldots \ldots \ldots \\
& \text { ここで, } \mathrm{X}_{\mathrm{R}} \text { は(10)式から, また } \mathrm{Y}_{\mathrm{o}}, \mathrm{Y}_{\mathrm{s}} \text { はおのおの }
\end{aligned}
$$
(1)，(2)式から算出可能であるから任意の条件下でのス ラリー残存率を導出でき，これより(19)式の滞留時間の 延長度合を示す指数 $\theta$ む算出可能となる。そこで，小 型連続装置 (Fig. 1) および 1t/d PDU の反応器の $\theta$ をワ ンドアン炭スラリー系について計算し，その結果を Fig. 11 亿示す。ここでは平均沸点の異なる溶剤を考 慮しているが, bp $270^{\circ} \mathrm{C}$ は小型装置で使用する疑似溶 剤(SS-1)，また $300^{\circ} \mathrm{C}$ はPDU での平衡溶剤の平均沸 点に対応する。

Fig. 11 より，平均沸点の低い溶剤を，あるいは小



$$
\begin{array}{cll}
\text { Symbol } & \text { BP }\left({ }^{\circ} \mathrm{C}\right) & \text { Reactor } \\
\text { (1) } & 270 & \text { Bench } \\
\text { (2) } & 300 & \text { Bench } \\
\text { (3) } & 270 & \text { PDU } \\
\text { (4) } & 300 & \text { PDU }
\end{array}
$$

Fig. 11 Relationship between $\mathrm{G} / \mathrm{L}$ and $\theta$ at $170 \mathrm{~kg} / \mathrm{cm}^{2} \mathrm{G}$

型装置のような $\varepsilon_{\mathrm{g}}$ の小さい反応器を使用した場合の方 が $\theta$ 大きくなることがわかる。さらにPDUのよう な $\varepsilon_{\mathrm{g}}$ の大きな反応器では, 低 $\mathrm{G} / \mathrm{L}$ 側では $\theta$ の向上度合 いが小さいことがわかる。したがって，G/Lによる 滞留時間の延長を効果的に発現させるためには, 比較 的低 $G / L$ で操作するプロセスでは $\varepsilon_{\mathrm{g}}$ を低く抑えるよ らな反応器を用い, 一方高 $\mathrm{G} / \mathrm{L}$ で操作する場合には 溶剤の平均沸点を低くすることが有効であると考えら れる。

\section{5 滞留時間延長方法と生成物分布}

スラリーの真の滞留時間が次式で示されることは明 かである。

$$
t_{R}=\theta \cdot t_{N}
$$

そこで，見かけの滞留時間 $\mathrm{t}_{\mathrm{N}}$ が異なりかつ $\mathrm{t}_{\mathrm{R}}$ が等 しくなるような条件を選択して実験を実施し，このと きの生成物分布について検討を行った。結果を Table 7 に示す。 $t_{\mathrm{N}}$ の増大によって $\mathrm{t}_{\mathrm{R}}$ が延長された結果に対 し, $\mathrm{G} / \mathrm{L}$ の増大によって $\mathrm{t}_{\mathrm{R}}$ を延長した場合にはガス, 軽質油収率が減少するものの中重質油の増加が顕著で, このためにトータルの液収率が增大していることがわ かる。これより，G/Lの増大によって軽質油, 中質油 等の成分の多くは蒸発して反応器から直ちに流出する ために過度な軽質化が抑制され，一方未反応残渣の滞 留時間は選択的に延長されるために，これの反応が促 進されて中質油等の成分に転化することが推察される。

故に, G/L の增大による滞留時間の延長は，ガス 收率の増加を引き起こすことなく液収率の増加を図る ことが可能であり, さらに中重質油留分の増加が顕著 であるといらことは溶剤バランスの点からも有利であ 
Table 7 Effect of $G / L$ on products yield distribution

\begin{tabular}{|c|c|c|c|c|c|c|c|c|}
\hline \multicolumn{3}{|c|}{ Reaction conditions } & \multicolumn{6}{|c|}{ Yield (wt $\%$, daf coal) } \\
\hline $\mathrm{G} / \mathrm{L}$ & $t_{N}$ & $t_{R}$ & Gas & Water & & - Oil - &  & Resid \\
\hline$(\ell / \ell)$ & $(\min )$ & $(\min )$ & & & $\mathrm{L}-\mathrm{O}$ & $\mathrm{H}-\mathrm{O}$ & Total & \\
\hline 9.5 & 118 & 184 & 19.8 & 6.8 & 29.3 & 24.0 & 53.3 & 24.2 \\
\hline 12.1 & 96 & 180 & 15.6 & 7.5 & 25.7 & 31.4 & 57.1 & 23.8 \\
\hline
\end{tabular}

Wandoan coal, $450^{\circ} \mathrm{C}, 150 \mathrm{~kg} / \mathrm{cm}^{2} \mathrm{G}$

ると考えられる。

\section{4. 結 論}

スラリー処理量 $5 \ell / \mathrm{h}$ 規模の小型連続装置を使用し てガス/スラリー供給量比 $(\mathrm{G} / \mathrm{L})$ の液化反応に対する 影響を検討すると共に, 反応器内での気液平衡状態を 解析した結果, 以下の結論を得た。

(1) G/Lを増大させると液収率が向上し，その関 係は(1)式で整理できた。

$$
\mathrm{Y}=\left(\mathrm{A} \sqrt{\mathrm{P}_{\mathrm{H}_{2}}}-\mathrm{B}\right)(\mathrm{G} / \mathrm{L})+\mathrm{C}
$$

（2）液化反応器内での溶剂の気液平衡状態を測定し たところ，G/L の増大と共に溶剤の蒸発量が増大し ていることが判明した。これょり，G/L増大に伴う 液収率向上の効果は, 石炭等の難蒸発成分の滞留時間 の延長として評価できることが推察された。

(3) 低 G/Lで操作するプロセスではガスホールド アップ $\left(\boldsymbol{\varepsilon}_{\mathrm{g}}\right)$ を抑制する形状の反応器を, また高 $\mathrm{G} / \mathrm{L}$ プロセスでは平均沸点の低い溶剤を用いる方が, G/Lによる滞留時間の延長が効果的に発現すること が予測された。

（4）スラリーの真の平均滞留時間 $\left(t_{R}\right)$ に対する
G/L なたはみかけの渔留時間の影響を検討したとこ ろ，G/Lの増大によって $t_{R}$ の延長を図った方が過度 な軽質化反応が抑制されるため, ガス収率が低下し逆 に液収率が向上することが判明した。

(謝辞)

本研究は, 新エネルギー総合開発機構 (NEDO) の 委託研究の一環として実施された。ここに深甚の謝意 を表する次第である。

\section{文献}

1）近田 司, 早川恵一, 燃協誌, $67,(5), 306$ (1988)

2) Hosoi, T. Yamada, T. and Hayakawa, K., Pan-Pacific Synfuels Conference(Tokyo), Vol.

I. p. 349(1982)

3）化学便覽基礎編 (丸善)， p. 701(1975)

4) Tarmy, B. L., Chang, M., Coulaloglou, C. A. and Ponzi, P. R., Inst. Chem. Eng. Symp. Ser., 87, $303(1984)$

5）石橋宏仁, 横山 敬, 酒井直秀, 小川高志, 第 23回石炭科学会議論文集, p. 241(1986)

\section{Role of Gas-Slurry Ratio in Coal Liquefaction Reaction}

\section{Tsukasa CHIKATA and Keiichi HAYAKaWA}

(Coal Liquefaction Development Department, Sumitomo Metal Industries, LTD.)

SYNOPSIS :- The effect of gas-slurry ratio $(\mathrm{G} / \mathrm{L})$ on coal liquefaction reaction and on the gas-liquid equilibrium in the liquefaction reactor were studied using a small bench scale flow unit. The results are summarized as follows:

(1) Oil yields were increased with the increase of the $\mathrm{G} / \mathrm{L}$ or/and the hydrogen partial pressure. From these results, equation (1) was obtained. 


$$
\mathrm{Y}=\left(\mathrm{A} \sqrt{\mathrm{P}_{\mathrm{H}_{2}}}-\mathrm{B}\right)(\mathrm{G} / \mathrm{L})+\mathrm{C}
$$

where

$$
\mathrm{Y}: \text { oil yield }[\mathrm{wt} \% \text {, daf coal] }
$$

$\mathrm{P}_{\mathrm{H}_{2}}$ : hydrogen partial pressure $\left[\mathrm{kg} / \mathrm{cm}^{2}\right]$

$\mathrm{G} / \mathrm{L}:$ gas/slurry ratio $[\ell / \ell]$

A,B,C : constants

(2) The increase of the $\mathrm{G} / \mathrm{L}$ promotes the solvent vaporization, therefore it is evaluated that the effect of the increase of $G / L$ on oil yields is caused by the increase of the residence time of the heavy fraction such as unreacted coal.

\section{Key Words}

Coal liquefaction, Gas-liquid equilibrium, Gas-slurry ratio, Gas holdup, Vapor pressure

\section{日本コークス標準試料}

コークス標準試料を本会で作製，ご希望の方に頒布致しております。この標準試料は分 析ならびにコークス取引関係者にとって必需のものであり，標準值表参考にお役に立てて いただきたく，ご購入方お勧め致します。

試料種類（約 $80 \mathrm{~g}$ 入，標準値表付） $\left\{\begin{array}{lllll}\text { I. } & \text { 低灰分 } \cdot \text { 中硫黄分 } \\ \mathrm{N} . & \text { 低 } & \text { 硫 } & \text { 黄 } & \text { 分 } \\ \mathrm{V} . & \text { 中 } & \text { 硫 } & \text { 黄 } & \text { 分 } \\ \mathrm{V} . & \text { 高 } & \text { 硫 } & \text { 黄 } & \text { 分 }\end{array}\right.$

販売価格 I. 5,000円 N. V. V. 各 1 瓶 6,000円（送料別）

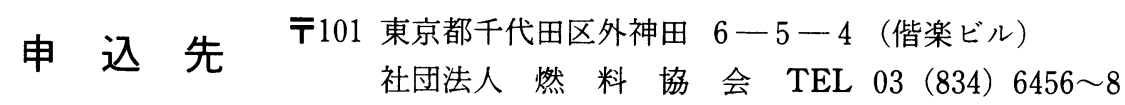

